\title{
Cognitive assessment in an elderly population with metabolic syndrome in Brazil
}

\author{
Nadia Shigaeff ${ }^{1,2}$, Alessandro Ferrari Jacinto ${ }^{1}$, Fabio Gazelato de Mello Franco², \\ Gabriela Chiochetta ${ }^{1}$, Maysa Seabra Cendoroglo ${ }^{1}$, Vanessa de Albuquerque Cítero ${ }^{1}$
}

\begin{abstract}
Chronic degenerative conditions are very common in the elderly. According to medical literature, there is a correlation between cognitive impairment among elders and arterial hypertension/hyperglycemia which in turn are common diseases among the elderly population worldwide. Nonetheless, data on the association between cognitive impairment and Metabolic Syndrome (MetS) remains controversial. Objective: To compare the cognitive status of Brazilian elderly outpatients with and without MetS. Methods: A cross-sectional case-control study with 49 subjects (25 MetS and 24 controls) who underwent a global geriatric and neuropsychological assessment was carried out. The scores for cognitive abilities (sustained attention, alternating attention, immediate memory, working memory, memory - immediate recall, memory - delayed recall, memory - recognition, executive function, ideomotor praxis, constructive praxis, naming ability, verbal fluency) were compared with the data for the normal population and differences between case and control groups were analyzed using Student's t-test or the Mann-Whitney test. Results: Forty-five patients (91.8\%) were female, with a mean age of $73.9 \pm 5.9$ years, and $3.0 \pm 1.0$ years of schooling. A significant difference $(p<0.01)$ was found between case and control groups regarding the MetS components. For cognitive abilities, no statistically significant difference was detected between the groups and all subjects presented low cognitive scores. Conclusion: The results obtained in the present study showed that MetS was not associated with cognitive impairment in this population. Further prospective studies are necessary to investigate the influence of well-controlled MetS on cognitive performance among elders.
\end{abstract}

Key words: metabolic syndrome X, neuropsychological tests, cognition disorders, memory, attention, elderly.

\section{AVALIAÇÃO COGNITIVA DE UMA POPULAÇÃO IDOSA COM SÍNDROME METABÓLICA NO BRASIL}

RESUMO. Quadros crônico-degenerativos são prevalentes na população idosa. Estudos prévios tem correlacionado prejuízo cognitivo em idosos com hipertensão e hiperglicemia que por sua vez são doenças bastante comuns do envelhecimento na população mundial. Apesar disso ainda existem dados controversos sobre a associação entre prejuízo cognitivo e síndrome metabólica (SMet). Objetivo: Comparar o estado cognitivo de pacientes brasileiros idosos em atendimento ambulatorial com e sem SMet. Métodos: Estudo de caso-controle transversal com 49 pacientes (25 com SMet e 24 controles) que foram submetidos à avaliação geriátrica global e neuropsicológica. Os escores de habilidades cognitivas (atenção sustentada, atenção alternada, memória imediata, memória operacional, memória tardia - evocação imediata, tardia e de reconhecimento -, função executiva, praxia ideomotora, praxia visuo-construtiva, habilidade de nomeação e fluência verbal) foram comparados com dados da população saudável e a diferença entre caso e controle foi analisada usando 0 teste t de Student ou o teste de Mann-Whitney. Resultados: Quarenta e cinco pacientes (91.8\%) foram mulheres com idade média de 73.9 \pm 5.9 anos e escolaridade média de $3.0 \pm 1.0$ anos. Observou-se uma diferença significativa $(p<0.01)$ entre os grupos com relação aos critérios da SMet. Com relação às habilidades cognitivas não houve diferença estatística entre os grupos e todos os pacientes apresentaram baixo escore cognitivo. Conclusão: Os resultados obtidos no presente estudo indicaram que a SMet não foi associada com o prejuízo cognitivo nesta população. Outros estudos prospectivos são necessários para melhor investigar a influência de idosos bem compensados nos componentes da SMet no desempenho cognitivo ao longo do tempo.

Palavras-chave: síndrome X metabólica, neuropsicologia, transtornos cognitivos, memória, atenção, idoso.

'Universidade Federal de São Paulo, São Paulo SP, Brazil; ${ }^{2 H o s p i t a l ~ I s r a e l i t a ~ A l b e r t ~ E i n s t e i n, ~ S a ̃ o ~ P a u l o ~ S P, ~ B r a z i l . ~}$

Vanessa de A. Citero. Department of Psychiatry, Escola Paulista de Medicina / Universidade Federal de São Paulo - Rua Borges Lagoa, 570 - $04038-020$ São Paulo SP - Brazil. E-mail address: vcitero@uol.com.br

Disclosure: The authors report no conflicts of interest.

Received March 30, 2012. Accepted in final form May 31, 2013. 


\section{INTRODUCTION}

The Brazilian population has aged in the last few dementia, are highly prevalent in the elderly. The identification of risk factors for cognitive impairment allows early detection of dementia states. ${ }^{3}$

Previous studies have shown correlation between cognitive impairment, arterial hypertension and serum hyperglycemia ${ }^{4,5}$ which are common diseases in the elderly population worldwide. Other studies have shown that elderly individuals with Metabolic Syndrome (MetS) have poor cognitive performance compared with subjects without MetS, especially on information processing speed, memory (immediate and delayed recall), mental flexibility, and also exhibit low scores on the Mini Mental State Examination (MMSE) ${ }^{6-8}$ These studies have also concluded that hyperglycemia is the main MetS factor involved in cognitive impairment.

According to the American Heart Association and the National Heart, Lung, and Blood Institute, ${ }^{9}$, the diagnosis of MetS has to meet three of the following five criteria: abdominal obesity defined as waist circumference $>102 \mathrm{~cm}$ in men and $>88 \mathrm{~cm}$ in women; serum triglycerides $\geq 150 \mathrm{mg} / \mathrm{dL}$ or specific drug treatment; serum HDL-cholesterol $<40 \mathrm{mg} / \mathrm{dL}$ in men and $<50 \mathrm{mg}$ / $\mathrm{dL}$ in women or specific drug treatment; arterial blood

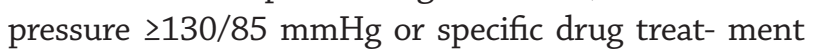
and fasting plasma glucose $\geq 100 \mathrm{mg} / \mathrm{dL}$ or specific drug treatment. Although each of the five criteria of MetS negatively influences cognition, it remains unclear whether MetS is a risk factor. ${ }^{10}$

The aim of the present study was to compare the cognitive status of Brazilian elderly outpatients with and without MetS.

\section{METHODS}

Subjects for this study were recruited from an Outpatient Geriatrics Service at the Hospital Israelita Albert Einstein and from the Universidade Federal de São Paulo, both situated in São Paulo, Brazil. All subjects agreed to participate in a one-year case-control follow-up which aimed to characterize the role of MetS in cerebral perfusion and cognition. The present manuscript is part of this research and reports cross-sectional data. The project was approved by the Institutional Research and Ethics Board of the Hospital Israelita Albert Einstein and of the Universidade Federal de São Paulo (process number: 09/1154 and 0306/10, respectively).

The elderly, all of whom were routinely followed at a MetS outpatient service, were invited to participate $(\mathrm{N}=37)$. The group comprised low-income individuals attended by the Brazilian Public Health Care System. The following inclusion criteria were adopted: be at least 65 years old, have 1 to 4 years of schooling and a score of 22 or higher on the Mini Mental State Examination (MMSE). ${ }^{11}$ The exclusion criteria were patients diagnosed with other neurodegenerative conditions, cerebrovascular disease or major psychiatric disorders. The final sample consisted of 25 subjects with MetS. There was no statistically significant difference between the included and excluded MetS subjects regarding gender and age.

Twenty-four healthy subjects with matched epidemiological characteristics and criteria were invited to participate in the control group. The control subjects attended community recreation centers for the elderly.

Subjects underwent global geriatric and neuropsychological assessment which included patients' medical background, a clinical assessment, blood tests and the neuropsychological tests described in Chart 1 . These tests $^{12}$ evaluate 12 abilities of cognition; the raw scores of the neuropsychological tests were weighted by age and schooling and converted into Z-scores (regarding RAVLT, gender was also considered). The Wechslers Digit Span was converted in weighted score according to the Wechslers Manual which presents the results weighted by age.

Data were analyzed using the Statistical Package for the Social Sciences 17.0. All variables were distributed in relation to presence or absence of MetS, using Student's t-test or the Mann-Whitney test.

\section{RESULTS}

Forty-five patients $(91.8 \%)$ were female, with a mean age of $73.9 \pm 5.9$ years, and $3.0 \pm 1.0$ years of schooling. A significant difference $(\mathrm{p}<0.01)$ was identified between case and control groups regarding waist circumference measures, fasting plasma glucose measures, HDL-cholesterol and triglycerides levels (Table 1).

Table 2 describes the cognitive performance of the 49 subjects. All mean scores of the abilities of sustained and alternating attention, executive function and memory (recognition) were impaired compared with standard healthy elderly in both groups of this study, given all had a Z-score lower than -0.7 . These data mean that participants' performances were lower than expected for their age, gender and schooling. There was no statistical difference between groups (MetS vs. control).

\section{DISCUSSION}

MetS affects both sexes and all ages and, in Latin America, the condition increases with age and is always more 
Chart 1. Description of 12 cognitive abilities evaluated by the eight tests applied in the study.

\begin{tabular}{lll}
\hline Abilities & Description & Tests \\
\hline Sustained Attention & Capacity to maintain an attentional activity over a period of time & Trail Making Test -TMT (Part A) \\
\hline Alternating Attention & Capacity to shift in focus and tasks & Trail Making Test - TMT (Part B) \\
\hline Immediate Memory & Capacity to grasp an adequate amount of information and recall it immediately & Digit Span - Direct Order (WAIS-III) \\
\hline Working Memory & Capacity to hold and manipulate information in mind for a short period of time & Digit Span - Reverse Order (WAIS-III) \\
\hline Memory - Immediate Recall & Capacity to recall the information immediately after the stimulus & Rey Auditory Verbal Learning - RAVLT \\
\hline Memory - Delayed Recall & Capacity to recall the information after a short period, usually 20 minutes after & Rey Auditory Verbal Learning - RAVLT \\
& the stimulus & \\
\hline Memory - Recognition & Capacity to recognize the information stored from a visual or verbal stimulus & Rey Auditory Verbal Learning - RAVLT \\
\hline Executive Function & Ability enabling the individual to create plans, goal-setting, strategies, make & Wisconsin Card Sorting Test - WCST \\
& decisions, monitoring, solving problems, mental flexibility and response initia- & \\
\hline tion and inhibition & Clock Drawing Test \\
\hline Constructive Praxis & Capacity to assemble, build and draw from a mental model & Cubes (WAIS- III) \\
\hline Naming Ability & Capacity to assemble, build and draw from a concrete model & Boston Naming Test - BNT \\
\hline Verbal Fluency & Capacity to name objects or pictures & FAS \\
\hline
\end{tabular}

Table 1. Distribution of means and standard deviation of metabolic parameters in subjects with and without metabolic syndrome.

\begin{tabular}{lccc}
\hline Parameters & $\begin{array}{c}\text { Control } \\
\text { Mean } \pm \text { SD }\end{array}$ & $\begin{array}{c}\text { Metabolic Syndrome } \\
\text { Mean } \pm \text { SD }\end{array}$ & P \\
\hline Systolic arterial pressure $(\mathrm{mmHg})^{\mathrm{a}}$ & $133.6 \pm 14.8$ & $139.0 \pm 22.8$ & 0.33 \\
\hline Diastolic arterial pressure $(\mathrm{mmHg})^{\mathrm{a}}$ & $78.2 \pm 10.1$ & $76.4 \pm 10.8$ & 0.54 \\
\hline Waist circumference $(\mathrm{cm})^{\mathrm{b}}$ & $91.1 \pm 11.8$ & $105.7 \pm 13.4$ & 0.000 \\
\hline Fasting plasma glucose $(\mathrm{mg} / \mathrm{dL})^{\mathrm{b}}$ & $84.4 \pm 9.3$ & $114.7 \pm 23.6$ & 0.000 \\
\hline HDL- cholesterol $(\mathrm{mg} / \mathrm{dL})^{\mathrm{a}}$ & $66.1 \pm 13.7$ & $51.2 \pm 13.8$ & 0.000 \\
\hline${\text { Triglycerides }(\mathrm{mg} / \mathrm{dL})^{\mathrm{a}}}$ & $90.0 \pm 35.3$ & $140.7 \pm 78.4$ & 0.006 \\
\hline
\end{tabular}

aStudent's t-test; ${ }^{b}$ Mann-Whitney U test.

Table 2. Distribution of means and standard deviation of cognitive abilities in subjects with and without metabolic syndrome.

\begin{tabular}{lccc}
\hline Parameters & $\begin{array}{c}\text { Control } \\
\text { Mean } \pm \text { SD }\end{array}$ & $\begin{array}{c}\text { Metabolic Syndrome } \\
\text { Mean } \pm \text { SD }\end{array}$ & P \\
\hline Sustained attention (Z-score) & $-3.1 \pm 3.5$ & $-4.9 \pm 4.4$ & 0.07 \\
\hline Alternating attention (Z- score) $^{\mathrm{b}}$ & $-4.8 \pm 5.8$ & $-9.0 \pm 19.8$ & 0.15 \\
\hline Working memory (Z-score) $^{\mathrm{a}}$ & $0.5 \pm 1.3$ & $0.9 \pm 1.3$ & 0.29 \\
\hline Immediate memory (Z-score) $^{\mathrm{a}}$ & $1.1 \pm 1.4$ & $1.1 \pm 1.0$ & 0.93 \\
\hline Mental flexibility (Z-score) & $-0.1 \pm 0.8$ & $-0.5 \pm 1.1$ & 0.27 \\
\hline Long memory - immediate recall (Z-score) $^{\mathrm{a}}$ & $-0.3 \pm 1.4$ & $-0.5 \pm 1.1$ & 0.58 \\
\hline Long memory - delayed recall (Z-score) $^{\mathrm{a}}$ & $-0.1 \pm 1.1$ & $-0.5 \pm 1.2$ & 0.23 \\
\hline Long memory - recognition (Z-score) $^{\mathrm{a}}$ & $-0.7 \pm 1.3$ & $-1.1 \pm 1.8$ & 0.31 \\
\hline Executive function (Z-score) $^{\mathrm{b}}$ & $-2.1 \pm 4.2$ & $-2.9 \pm 4.6$ & 0.38 \\
\hline Constructive praxis (weighted) & $9.7 \pm 2.4$ & 0.87 \\
\hline Naming ability (Z-score) & $-0.0 \pm 1.2$ & $-0.4 \pm 1.1$ & 0.15 \\
\hline Verbal fluency (Z-score) & $-0.1 \pm 0.7$ & $-0.4 \pm 0.6$ & 0.09 \\
\hline
\end{tabular}

aStudent's t-test; ${ }^{b}$ Mann-Whitney U test. 
prevalent in women, especially those from lower social strata. ${ }^{6,13}$ Considering this profile, the study sample was representative of MetS patient characteristics. Another relevant aspect is that the patients were also a representative part of the Brazilian elderly population regarding schooling. ${ }^{1}$ As previously recognized in other Brazilian studies, schooling is an important issue in this field of research because high educational level has a protective affect against cognitive impairment. ${ }^{14-16}$ The lack of Brazilian validated versions of some neuropsychological instruments makes it difficult to elucidate the poor performance of our subjects. Most of the instrument scores (except Wechsler's subtests and Wisconsin Card Sorting Test) were previously obtained from American individuals and the low performance of both groups on these tests could be related to the fact that educational levels of Brazilians are lower than Americans.
Notwithstanding, no difference was observed between the groups in the sample for the cognitive performance parameter.

This could indicate that MetS elderly outpatients are more likely to be cognitively preserved, as proposed by previous studies. ${ }^{10,17}$

From a clinical point of view, both case and control groups of elderly subjects were cognitively preserved since they were independent and all came unaccom- panied to the hospital. Therefore, these results are in agreement with previously reported data on preserved and well-controlled MetS aging. ${ }^{10}$ The controversy over the association between cognitive im- pairment and MetS remains unclear in elderly subjects with low schooling. Further studies, particularly those with a prospective design, are necessary to explore cognitive abilities in patients with MetS.

\section{REFERENCES}

1. Instituto Brasileiro de Geografia e Estatística. Perfil dos Idosos Responsáveis pelos Domicílios no Brasil - 2000, 9. Retrieved from: http://www. ibge.gov.br/home/estatistica/populacao/perfilidoso/perfidosos2000. pdf; 2002.

2. Instituto Brasileiro de Geografia e Estatística. Indicadores sócio-demográficos e de saúde no Brasil- 2009, 25. Retrieved from: http:// www.ibge.gov.br/home/estatistica/populacao/indic_sociosaude/2009/ indicsaude.pdf; 2009.

3. Jacinto AF, Brucki S, Porto CS, Martins MA, Nitrini R. Detection of cognitive impairment in the elderly by general internists in Brazil. Clinics 2011;66:1379-1384.

4. Yaffe K, Blackwell T, Kanaya AM, Davidowitz N, Barrett-Connor E, Krueger K. Diabetes, impaired fasting glucose, and the development of cognitive impairment in older women. Neurology 2004;63:658-663.

5. Yeung SE, Thorton WL. Age-related effects of blood pressure on everyday cognitive function in community-dwelling women. Neuropsychol Dev Cogn B Aging Neuropsychol Cogn 2011;18:733-755.

6. Cuevas A, Alvarez V, Carrasco F. Epidemic of metabolic syndrome in Latin America. Curr Opin Endocrinol Diabetes Obes 2011;18(2):134-138.

7. Dik MG, Jonker C, Cumijs HC, et al. Contribuition of Metabolic Syndrome Components to Cognition in Older Individuals. Diabetes Care 2007;30:2655-2660.

8. Grundy SM, Cleeman JI, Daniel SR, et al. Diagnosis and management of the metabolic syndrome: an American Heart Association/National Heart, Lung, and Blood Institute Scientific Statement. Circulation 2005; 112:2735-2752.

9. Hoth KF, Gonzales MM, Tarumi T, Miles SC, Tanaka H, Haley AP. Func-

tional MR Imaging Evidence of Altered Functional Activation in Metabolic Syndrome. AJNR Am J Neuroradiol 2001;32:541-547.

10. Yaffe K. Metabolic syndrome and cognitive disorders: is the sum greater than its parts? Alzheimer Dis Assoc Disord 2007;21: 167-171.

11. Brucki SMD, Nitrini R, Caramelli P, Bertolucci PHF, Okamoto $H$. Suggestions for use of the Mini Mental State Exam in Brazil. Arq Neuropsiquiatr 2003;61:777-781.

12. Lesak MD, Howieson DB, Loring DW. Basic Concepts. In: Neuropsy chological Assessement (4rd Ed). New York: Oxford University Press; 2004:15-38.

13. Aballay LR, Eynard AR, Díaz M del P, Navarro A, Muñoz SE. Overweight and obesity: a review of their relationship to metabolic syndrome, cardiovascular disease, and cancer in South America. Nutr Rev 2013;71(3):168-179.

14. Caramelli P, Carthery-Goulart MT, Porto CS, Charchat-Fichman H, Nitrini R. Category Fluency as a Screening Test for Alzheimer Disease in Illiterate and Literate Patients. Alzheimer Dis Assoc Disord 2007;21:65-67.

15. Laks J, Coutinho ESF, Junger W, et al. Education does not equally influence all the Mini Mental State Examination subscales and items: inferences from a Brazilian community sample. Rev Bras Psiquiatr 2010;32:223-230.

16. Lourenço RA, Ribeiro-Filho ST, Moreira IFH, Paradela EMP, Miranda AS. The Clock Drawing Test: performance among elderly with low educational level. Rev Bras Psiquiatr 2008;30:309-315.

17. Roberts RO, Geda YE, Knopman DS, et al. Metabolic Syndrome, Inflammation, and Non-Amnestic Mild Cognitive Impairment in Older Persons: a population-based study. Alzheimer Dis Assoc Disord 2010;24:11-18. 